\title{
Dielectric Relaxation and Water Activity in Aqueous Solution of D-Psicose
}

\author{
Shinya IKEDA ${ }^{1, \dagger}$, Shoichi GOHTANI ${ }^{1}$, Kazuhiro FUKADA ${ }^{1}$, and Yuko AMO ${ }^{2}$ \\ ${ }^{1}$ Faculty of Agriculture, Kagawa University, 2393 Ikenobe, Miki-cho, Kita-gun, Kagawa 761-0795, Japan \\ ${ }^{2}$ Faculty of Science, Yamagata University, 1-4-12 Kojirakawa-machi, Yamagata 990-8560, Japan
}

\begin{abstract}
Hydration behavior of a rare sugar, D-psicose, was investigated based on measurements of the dielectric relaxation and the water activity in its aqueous solutions. Dielectric relaxation spectra in the frequency domain were obtained from time domain reflectometry. The dielectric relaxation time was then determined by fitting the spectra to a Cole-Cole type equation and used to evaluate the average hydration number representing the average number of water molecules forming a complex with a sugar molecule at infinite dilution. The concentration dependence of the dielectric relaxation time in aqueous solutions of all examined sugars generated a single master curve. The average hydration number of psicose was found to be identical with that of fructose. Only slight differences were noticeable among the concentration dependences of the water activity of monosaccharides. The equilibrium constant of hydration of sugar was calculated by considering material balances in an aqueous solution of sugar and using experimentally obtained values of the average hydration number and the water activity. The equilibrium constant values increased in the order of glucose $<$ fructose $\approx$ psicose $<$ trehalose $<$ sucrose $<$ maltose. The present results suggest that both fructose and psicose interact with water in a similar manner.
\end{abstract}

Key words: dielectric relaxation, hydration, rare sugar, time domain reflectometry, water activity

\section{Introduction}

Rare sugars are sugars that rarely exist in nature or exist in small quantities in nature [1,2]. D-Psicose is one of the first rare sugars of which commercial production process has been established [1,2]. Due to limited availabilities of rare sugars, their physicochemical properties $[3,4]$ as well as physiological functions have not been fully explored. The sweetness of psicose is said to be approximately $70 \%$ of that of sucrose, while its energy value corresponds to $0.3 \%$ only [5]. Evidence for promising health benefits such as anti-oxidation effects [6], reduction in the glycemic index [7], promotion of the blood insulin level [7], and anti-athereosclerosis effects [8] is emerging.

Hydration of sugar has significant implications in food preservation $[9,10]$. Thus, various physicochemical techniques including dielectric relaxation [11,12], differential scanning calorimetry [13], nuclear magnetic resonance [13,14], ultrasonic velocity [12,15], viscosity [3], and water activity measurements [16,17] have been applied to elucidate the interaction between sugar and water mol-

(Received 31 Jan. 2011: accepted 25 Mar. 2011)

$\dagger$ Fax: +81-87-891-3021, E-mail: sikeda@ag.kagawa-u.ac.jp ecules in aqueous systems. It remains to be difficult, however, to systematically understand the mechanism of hydration of sugar. For example, it is possible to quantify the number of hydrated water molecules per sugar molecule (i.e., the hydration number) experimentally, while experimentally evaluated values of the hydration number show great discrepancies, depending on the time scale of perturbation employed in the experimental method [9].

Matsuoka et al. have conducted density and ultrasonic velocity measurements to evaluate the partial molar volume and the partial molar compressibility of two disaccharides, maltose and trehalose [12]. The hydration number of trehalose evaluated from the partial molar volume and compressibility was found to be approximately $10 \%$ larger than that of maltose. Furthermore, the data of the dielectric relaxation time in aqueous solutions of trehalose and maltose generated a single master curve when it is plotted as a function of the product of the hydration number and the mole fraction of the sugar. These results indicate a practical approach for evaluating the hydration number of sugars based on the measurement of the dielectric relaxation time in aqueous solutions of sugar.

It is desirable for comparison purposes to evaluate hydration numbers of various sugars using an identical 
experimental method. In this study, dielectric relaxation measurements have been adopted to evaluate the hydration number of three monosaccharides including D-psicose and three disaccharides. The equilibrium constant of hydration has been evaluated using the hydration number and water activity.

\section{Theory}

Gaïda et al. have proposed a simplified model for describing hydration of sugar in an aqueous solution by assuming that one sugar molecule forms one complex with $n$ molecules of water, where $n$ is the hydration number [9]. This model enables us to predict various physical properties of sugar-containing food such as the boiling point, the freezing point, the osmotic pressure, and so on with known values of the hydration number $n$ and the equilibrium constant of the hydration reaction $K$ [9].

From material balances of three chemical species (i.e., free water, free sugar, and sugar $n$-hydrate), the following equations are obtained.

$$
\begin{gathered}
n_{\mathrm{w}}^{\mathrm{a}}=n_{\mathrm{w}}+n n_{\mathrm{h}} \\
n_{\mathrm{s}}^{\mathrm{a}}=n_{\mathrm{s}}+n_{\mathrm{h}}
\end{gathered}
$$

where $n_{\mathrm{w}}^{\mathrm{a}}$ is the apparent (total) amount of water in units of moles, $n_{\mathrm{w}}$ is the amount of free water in units of moles, $n_{\mathrm{h}}$ is the amount of sugar $n$-hydrate in units of moles, $n_{\mathrm{s}}^{\mathrm{a}}$ is the apparent (total) amount of sugar in units of moles, and $n_{\mathrm{s}}$ is the amount of free sugar in units of moles. The mole fraction of free water $x_{\mathrm{w}}$ is given by

$$
x_{\mathrm{w}}=\frac{n_{\mathrm{w}}}{n_{\mathrm{w}}+n_{\mathrm{s}}+n_{\mathrm{h}}}=\frac{n_{\mathrm{w}}^{\mathrm{a}}-n n_{\mathrm{h}}}{n_{\mathrm{w}}^{\mathrm{a}}+n_{\mathrm{s}}^{\mathrm{a}}-n n_{\mathrm{h}}}
$$

The amount of sugar $n$-hydrate can be then expressed by the following equation:

$$
n_{\mathrm{h}}=\frac{\left(x_{\mathrm{w}}^{a}-x_{\mathrm{w}}\right)\left(n_{\mathrm{w}}^{a}+n_{\mathrm{s}}^{a}\right)}{n\left(1-x_{\mathrm{w}}\right)}
$$

where $\left.x_{\mathrm{w}}^{\mathrm{a}}\left(=n_{\mathrm{w} /}^{\mathrm{a}} n_{\mathrm{w}}^{\mathrm{a}}+n_{\mathrm{s}}^{\mathrm{a}}\right)\right)$ is the apparent mole fraction of water. The mole fraction of sugar $n$-hydrate $x_{\mathrm{h}}$ is then related to the apparent mole fraction of water, the mole fraction of free water, and the hydration number by

$$
x_{\mathrm{h}}=\frac{n_{\mathrm{h}}}{n_{\mathrm{w}}+n_{\mathrm{s}}+n_{\mathrm{h}}}=\frac{x_{\mathrm{w}}^{\mathrm{a}}-x_{\mathrm{w}}}{n\left(1-x_{\mathrm{w}}^{\mathrm{a}}\right)}
$$

The equilibrium constant of hydration $K$ can be defined as

$$
K=\frac{a_{\mathrm{h}}}{a_{\mathrm{s}} a_{\mathrm{w}}^{n}}
$$

where $a_{\mathrm{h}}, a_{\mathrm{s}}$, and $a_{\mathrm{w}}$ are the activities of sugar $n$-hydrate, free sugar, and free water, respectively. The following relationships have been derived from thermodynamic consideration [9].

$$
\begin{gathered}
a_{\mathrm{h}}=\gamma_{\mathrm{h}} x_{\mathrm{h}} \\
a_{\mathrm{s}}=\gamma_{\mathrm{s}} x_{\mathrm{s}}=\gamma_{\mathrm{s}}^{\mathrm{a}} x_{\mathrm{s}}^{\mathrm{a}}=a_{\mathrm{s}}^{\mathrm{a}} \\
a_{\mathrm{w}}=\gamma_{\mathrm{w}} x_{\mathrm{w}}=\gamma_{\mathrm{w}}^{\mathrm{a}} x_{\mathrm{w}}^{\mathrm{a}}=a_{\mathrm{w}}^{\mathrm{a}}
\end{gathered}
$$

where $a_{\mathrm{s}}^{\mathrm{a}}$ is the apparent activity of sugar, $a_{\mathrm{w}}^{\mathrm{a}}$ is the apparent water activity, $\gamma_{\mathrm{h}}, \gamma_{\mathrm{s}}$, and $\gamma_{\mathrm{w}}$ are true activity coefficients of sugar $n$-hydrate, free sugar, and free water, respectively; $\gamma_{\mathrm{s}}^{\mathrm{a}}$ and $\gamma_{\mathrm{w}}^{\mathrm{a}}$ are apparent activity coefficients of sugar and water, respectively; $x_{\mathrm{s}}$ is the mole fraction of free sugar, and $x_{\mathrm{s}}^{\mathrm{a}}\left(=n_{\mathrm{s} /}^{\mathrm{a}}\left(n_{\mathrm{w}}^{\mathrm{a}}+n_{\mathrm{s}}^{\mathrm{a}}\right)\right)$ is the apparent mole fraction of sugar.

Results from many experimental techniques including dielectric relaxation spectroscopy are spatially averaged over a number of molecules in the sample. The average hydration number $n_{\mathrm{a}}$ that can be determined from such an experiment is defined as

$$
n_{\mathrm{a}}=n \frac{x_{\mathrm{h}}}{x_{\mathrm{s}}+x_{\mathrm{h}}}=n \frac{\frac{\gamma_{\mathrm{s}}}{\gamma_{\mathrm{h}}} K a_{\mathrm{w}}^{n}}{1+\frac{\gamma_{\mathrm{s}}}{\gamma_{\mathrm{h}}} K a_{\mathrm{w}}^{n}}
$$

\section{Experimental}

\subsection{Materials}

D-Psicose (Lot No. 040506) was obtained from Kagawa Rare Sugar Cluster (Kagawa, Japan). Sucrose, potassium chloride, potassium nitrate, potassium sulfate, and sodium chloride were purchased from Nacalai Tesque Co. (Kyoto, Japan). The water content in sugar was determined by drying in an oven at ca. $110^{\circ} \mathrm{C}$ until a constant weight has been achieved. All the chemicals were of reagent grade quality and used without further purification.

\subsection{Time domain reflectometry (TDR)}

A voltage pulse of $200 \mathrm{mV}$ in amplitude was applied to a sample solution through a coaxial cable and the timedependent change in the voltage of the reflected wave was measured using an HP54121T digitizing oscilloscope consisting of an HP54120B mainframe and an HP54121A four channel test set (Hewlett-Packard, USA). The com- 
plex permittivity in the frequency domain was then evaluated based on the following equations [18-21].

$$
\begin{gathered}
\varepsilon_{\mathrm{x}}^{*}(\omega)=\varepsilon_{\mathrm{s}}^{*}(\omega) \frac{1+\left\{\mathrm{c} f_{\mathrm{s}}(\omega) /\left[i \omega \gamma_{\mathrm{d}} \varepsilon_{\mathrm{s}}^{*}(\omega)\right]\right\} \rho(\omega) f_{\mathrm{x}}(\omega)}{1+\left\{\left[i \omega \gamma_{\mathrm{d}} \varepsilon_{\mathrm{s}}^{*}(\omega)\right] / \mathrm{c} f_{\mathrm{s}}(\omega)\right\} \rho(\omega) f_{\mathrm{s}}(\omega)} \\
\rho(\omega)=\frac{r_{\mathrm{s}}(\omega)-r_{\mathrm{x}}(\omega)}{r_{\mathrm{s}}(\omega)+r_{\mathrm{x}}(\omega)} \\
f_{\mathrm{x}}(\omega)=Z_{\mathrm{x}}(\omega) \cot Z_{\mathrm{x}}(\omega) \\
Z_{\mathrm{x}}(\omega)=\frac{\omega d}{c} \sqrt{\varepsilon_{\mathrm{x}}^{*}(\omega)} \\
f_{\mathrm{s}}(\omega)=Z_{\mathrm{s}}(\omega) \cot Z_{\mathrm{s}}(\omega) \\
Z_{\mathrm{s}}(\omega)=\frac{\omega d}{c} \sqrt{\varepsilon_{\mathrm{s}}^{*}(\omega)}
\end{gathered}
$$

where $\varepsilon_{\mathrm{x}}^{*}(\omega)\left(=\varepsilon^{\prime}-i \varepsilon^{\prime \prime}\right)$ is the complex permittivity of the sample, $\omega$ is the angular frequency, $\varepsilon_{\mathrm{s}}^{*}(\omega)$ is the complex permittivity of the reference sample with known permittivity, $c$ is the speed of propagation of the pulse $i n$ vacuo, $d$ is the geometric cell length, $i$ is an imaginary unit, $\gamma_{\mathrm{d}}$ is the effective cell length, and $r_{\mathrm{s}}$ and $r_{\mathrm{x}}$ are Fourier transforms of the reflected wave from the reference and that from the sample, respectively. Measurements were performed at $25^{\circ} \mathrm{C}$ using air as the reference. The effective cell length $\gamma_{\mathrm{d}}$ was determined so that the dielectric constant of water at the low frequency limit agrees with the known value in the literature [22]. Sample solutions containing 20\% (w/w), 30\% $(\mathrm{w} / \mathrm{w}), 40 \%(\mathrm{w} / \mathrm{w})$, or $50 \%(\mathrm{w} / \mathrm{w})$ of $\mathrm{D}-\mathrm{psicose}$ were prepared by stirring mixtures of $\mathrm{D}$-psicose and water in sealed containers overnight using a magnetic stirrer. Aqueous solutions of sucrose containing 20\% (w/w), 30\% $(\mathrm{w} / \mathrm{w}), 40 \%(\mathrm{w} / \mathrm{w})$, or $50 \%(\mathrm{w} / \mathrm{w})$ of sucrose were also prepared for TDR experiments by stirring mixtures of sucrose and water in sealed containers overnight using a

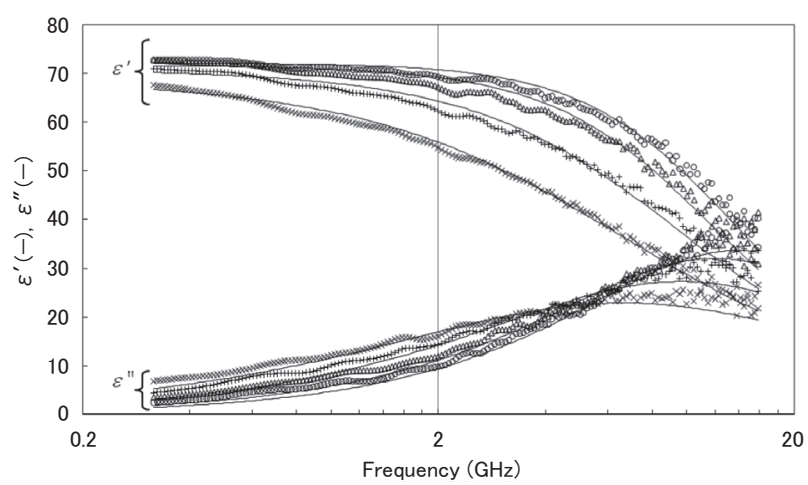

Fig. 1 Dielectric relaxation spectra of aqueous solutions of D-psicose. $\bigcirc, 20 \%$ w/w; $\triangle, 30 \%$ w/w; +, 40\% w/w; × , 50\% w/w. Solid curves are fitted using Equation (17). magnetic stirrer since no reported data in the literature were found to be suitable for the present analysis explained below.

The dielectric relaxation of a sugar solution is known to be well-described by the following Cole-Cole type relaxation $[11,12]$.

$$
\varepsilon_{\mathrm{x}}^{*}(\omega)=\varepsilon_{\infty}+\frac{\Delta \varepsilon}{1+(i \omega \tau)^{\beta}}
$$

where $\varepsilon_{\infty}$ is the dielectric constant at the high frequency limit, $\Delta \varepsilon$ is the relaxation strength, $\tau$ is the dielectric relaxation time, and $\beta(0<\beta<1)$ is a constant reflecting the distribution of the relaxation time. The dielectric relaxation time in an aqueous solution of sugar was evaluated by fitting complex permittivity data to Equation (17) using a least-squares method.

\subsection{Water activity}

Sample solutions containing 20\% (w/w), 30\% (w/w), $40 \%(\mathrm{w} / \mathrm{w})$, or $50 \%(\mathrm{w} / \mathrm{w})$ of $\mathrm{D}-\mathrm{psicose}$ were prepared by stirring mixtures of $\mathrm{D}^{-}$psicose and water in sealed containers overnight using a magnetic stirrer. The apparent water activity $a_{\mathrm{w}}^{\mathrm{a}}$ of a sample solution was determined based on the measurement of the relative humidity in the air equilibrated with the solution using a TH2/RTD-33/ BS thermoconstanter (Novasina, Zurich, Switzerland). Calibration was conducted prior to measurements using saturated salt solutions of potassium chloride, potassium nitrate, potassium sulfate, and sodium chloride with known water activity values [23]. Measurements were performed at $25^{\circ} \mathrm{C}$.

\section{Results and discussion}

\subsection{Average hydration number}

Dielectric relaxation spectra obtained for aqueous

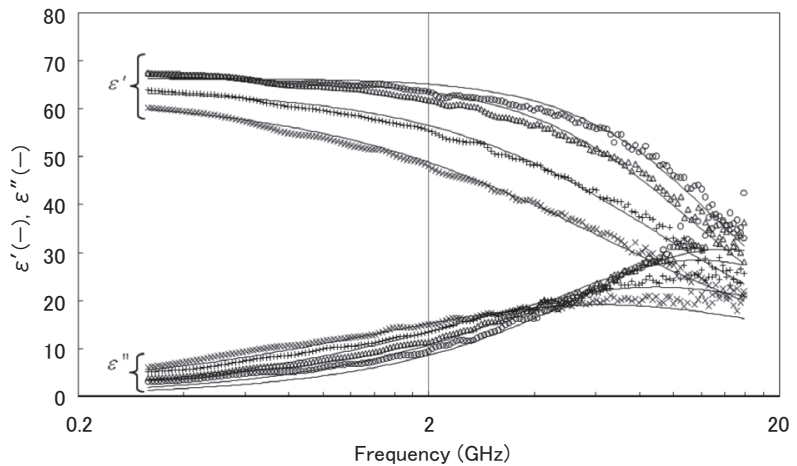

Fig. 2 Dielectric relaxation spectra of aqueous solutions of sucrose. $\bigcirc, 20 \% \mathrm{w} / \mathrm{w} ; \triangle, 30 \% \mathrm{w} / \mathrm{w} ;+$, $40 \% \mathrm{w} / \mathrm{w} ; \times$, $50 \% \mathrm{w} / \mathrm{w}$. Solid curves are fitted using Equation (17). 
solutions of D-psicose and sucrose are shown in Figs. 1 and 2 , respectively. It can be seen in both the figures that the dielectric constant at the low frequency limit decreases with increasing sugar concentration and that the spectrum shifts toward lower frequency with increasing sugar concentration. Due to the limited width of the accessible frequency range, it was difficult to determine the dielectric constant at the high frequency limit $\varepsilon_{\infty}$ by fitting data to Eq. (17). Therefore, values of $\varepsilon_{\infty}$ of D-psicose and sucrose were estimated by assuming a linear relationship between $\varepsilon_{\infty}$ and the weight fraction of each sugar and using literature values of $\varepsilon_{\infty}$ for pure water [24] and a $50 \%(\mathrm{w} / \mathrm{w})$ maltose or trehalose solution [12]. The complex permittivity data were then fitted to the Cole-Cole equation (i.e., Equation (17)). The dielectric relaxation time $\tau$ of water evaluated based on the present method was $8.9 \mathrm{ps}$, consistent with literature values $[22,24]$. Furthermore, changes in evaluated values of $\tau$ by changing $\varepsilon_{\infty}$ between 3.7 (i.e., the literature value for a $50 \%$ maltose or trehalose solution [12]) and 5.5 (i.e., the literature value for water [24]) for fitting the dielectric relaxation data of both $\mathrm{D}^{-}$psicose and sucrose to Eq.

(17) were confirmed to be less than $0.1 \mathrm{ps}$.

Figure 3 reveals approximately linear relationships between the logarithm of the dielectric relaxation time evaluated using the Cole-Cole equation and the mole fraction of sugar. Values of $\tau$ at a certain mole fraction were almost identical among monosaccharides but increased in the order of monosaccharides < sucrose <

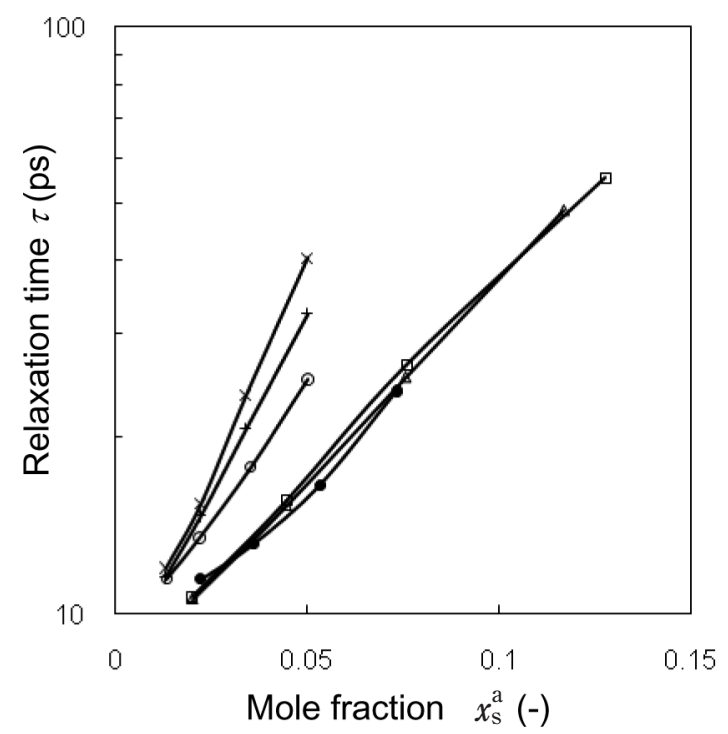

Fig. 3 Dielectric relaxation time in aqueous solutions of monoand disaccharides as a function of the mole fraction. $\triangle$, fructose [11]; $\square$, glucose [11]; $\bullet$, psicose; + , maltose [12]; $\bigcirc$, sucrose; $\mathbf{x}$, trehalose [12]. The solid curves are to guide the eye. maltose $<$ trehalose, indicating that the total amount of hydrated water in the sugar solutions might increase in this order. The complex permittivity is related to the autocorrelation function of the dipole moment density in the material of interest and the relaxation time is the time constant in the rate of exponential decay of the orientation polarization moment [12]. Therefore, the dielectric relaxation time in a sugar solution is considered to reflect the effect of hydration of sugar on the dipole moment density, not the rotational relaxation of individual chemical species such as free water, free sugar, and sugar-water complex in the solution.

Matsuoka et al. have evaluated the average hydration number $n_{\mathrm{a}}$ of maltose and trehalose based on the partial molar volume and the partial molar compressibility at infinite dilution [12]. When the dielectric relaxation time $\tau$ is plotted against $n_{\mathrm{a}} x_{\mathrm{s}}^{\mathrm{a}}$, both the data for maltose and trehalose have fallen on an identical curve, suggesting that the total amount of hydrated water in sugar solutions can be estimated as a product of the average hydration number and the mole fraction of sugar. The $\tau-n_{\mathrm{a}} x_{\mathrm{s}}^{\mathrm{a}}$ curve constructed by Matsuoka et al. is used in this study as reference to evaluate the average hydration number of fructose, glucose, D-psicose, and sucrose. The data of the dielectric relaxation time of these sugars were fitted to the curve obtained for maltose and trehalose using a least-squares method (Fig. 4). Good correlations between $\tau$ and $n_{\mathrm{a}} x_{\mathrm{s}}^{\mathrm{a}}$ were observed for all examined sugars. Evaluated values of the average hydration

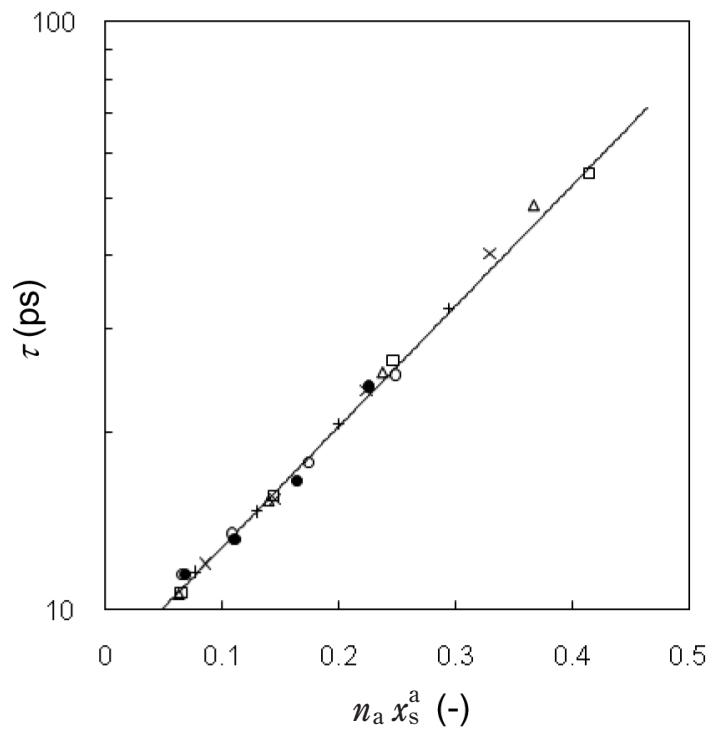

Fig. 4 Correlation between the dielectric relaxation time and the product of the mole fraction and the average hydration number. $\triangle$, fructose; $\square$, glucose; $\odot$, psicose; + , maltose [12]; $\bigcirc$, sucrose; $\times$, trehalose [12]. The solid line is to guide the eye. 
number are listed in Table 1 . Considering the grate variation in the hydration number determined from varied experimental methods, it seems to be rather surprising that the average hydration number of $\mathrm{D}$-psicose evaluated from the dielectric relaxation time in this study has coincided with that from viscosity measurements [3]. Additionally, this value also coincided with the average hydration number of fructose evaluated from the dielectric relaxation time. Psicose is an epimeric stereoisomer of fructose: the only difference in the chemical structure is the position of the C-3 hydroxyl group [4]. The structural similarity between psicose and fructose should play a certain role in providing an identical average hydration number although the equilibrium contents of the tautomers in an aqueous solution are known to differ greatly between $\mathrm{D}^{-}$psicose and fructose [4].

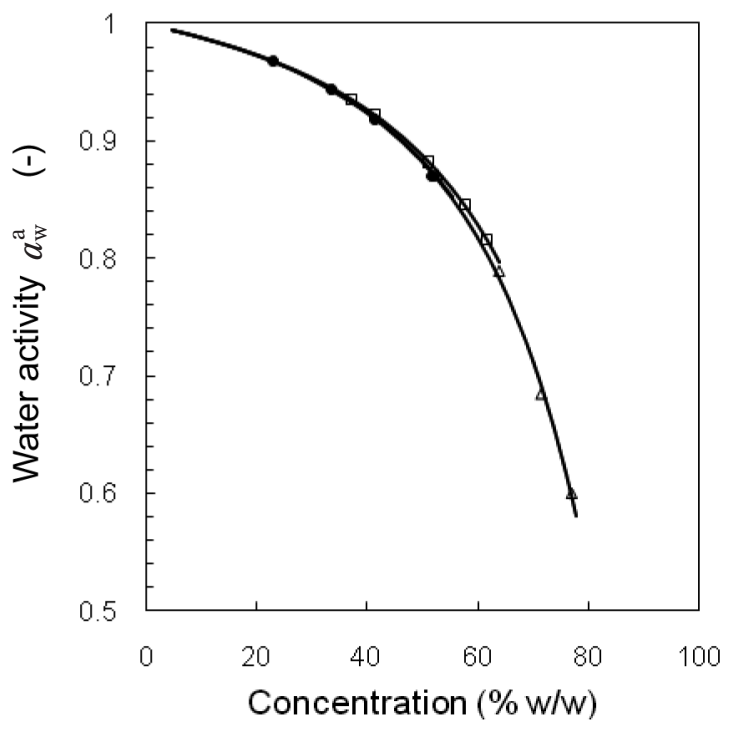

Fig. 5 Concentration dependence of the water activity of monosaccharide aqueous solutions. $\triangle$, fructose [10]; $\square$, glucose [10]; 0 , psicose. Solid curves are fitted using Equation (18).
The present approach gives a single value of the average hydration number for each sugar in the examined concentration range; however, the hydration number of sugar $n$ is expected to decrease with increasing concentration of sugar since sugar-sugar interactions become more predominant over sugar-water interactions. A decrease in the hydration number might be indicated in a $\tau-n_{\mathrm{a}} x_{\mathrm{s}}^{\mathrm{a}}$ plot as a decrease in the slope of the curve, while no change in the slope is noticeable in Fig. 4. These results suggest two possibilities: (1) a change in the hydration number is negligible in the examined concentration range, and (2) effects of changes in the hydration number are cancelled by effects of changes in $\tau$. An alternative approach is needed to test the validity of these hypotheses.

\subsection{Equilibrium constant of hydration and hydration number}

Apparent water activities $a_{\mathrm{w}}^{\mathrm{a}}$ of aqueous solutions of monosaccharides are compared in Fig. 5. Values of $a_{\mathrm{w}}^{\mathrm{a}}$ were almost identical at a certain concentration among the three monosaccharides examined. The data were fitted to the following empirical equation $[16,17]$ using a least-squares method.

$$
a_{\mathrm{w}}^{\mathrm{a}}=\left(1-x_{\mathrm{s}}^{\mathrm{a}}\right) \exp \left(\alpha x_{\mathrm{s}}^{\mathrm{a}} x_{\mathrm{s}}^{\mathrm{a}}\right)
$$

where $\alpha$ is a constant reflecting the concentration dependence of the water activity. Good agreements between the data and Equation (18) can be seen in Fig 5 . Values of $\alpha$ obtained from the curve fitting analysis are summarized in Table 1. Miyawaki and co-workers $[16,17]$ calculated the water activity in sugar solutions from the measurement of the freezing point depression and evaluated the parameter $\alpha$. They have revealed that

Table 1 Hydration number, parameter $\alpha$ in Equation (18), and equilibrium constant of hydration for mono- and disaccharides.

\begin{tabular}{|c|c|c|c|c|c|c|}
\hline \multirow[b]{2}{*}{ Fructose } & \multirow{2}{*}{$\begin{array}{c}n_{\mathrm{a}} \\
3.1 \\
3.0-16.5^{\mathrm{a}}\end{array}$} & \multirow{2}{*}{$\begin{array}{c}n \\
4.6 \\
3.39^{\mathrm{a}}\end{array}$} & \multicolumn{2}{|c|}{$\alpha$} & \multicolumn{2}{|c|}{$K$} \\
\hline & & & -3.597 & $-2.009^{b}$ & $2.11^{c}$ & $0.74^{\mathrm{d}}$ \\
\hline Glucose & $\begin{array}{c}3.2 \\
3.0-18.6^{a}\end{array}$ & $\begin{array}{c}5.5 \\
1.93^{\mathrm{a}} \\
\end{array}$ & -2.898 & $-2.734^{b}$ & $1.43^{\mathrm{e}}$ & $1.29^{\mathrm{f}}$ \\
\hline Psicose & $\begin{array}{c}3.1 \\
3.1^{\mathrm{g}}\end{array}$ & 4.5 & & & & \\
\hline Maltose & $\begin{array}{c}5.9^{\mathrm{h}} \\
5-27.2^{\mathrm{a}}\end{array}$ & $\begin{array}{c}7.6 \\
4.48^{\mathrm{a}}\end{array}$ & & & & \\
\hline Sucrose & $\begin{array}{c}5.0 \\
5.3-25.2^{\mathrm{a}}\end{array}$ & $\begin{array}{c}6.6 \\
3.13^{\mathrm{a}}\end{array}$ & & & & \\
\hline Trehalose & $\begin{array}{c}6.6^{\mathrm{h}} \\
6.6-15.3^{\mathrm{a}}\end{array}$ & $\begin{array}{c}9.1 \\
5.80^{\text {a }}\end{array}$ & & & & \\
\hline
\end{tabular}


the parameter $\alpha$ can be regarded as an index of the solvent-ordering since good correlations have been confirmed between $\alpha$ and various solvent-ordering parameters determined based on independent experiments including the measurement of the dielectric relaxation time [25]. As shown in Table 1, the measurement of the vapor pressure tended to give a value of $\alpha$ smaller than that evaluated from the measurement of the freezing point depression for unknown reasons.

The establishment of Equation (18) allows the evaluation of the apparent activity of sugar $a_{\mathrm{s}}^{\mathrm{a}}$ using the following Gibbs-Duhem relationship.

$$
x_{\mathrm{w}}^{\mathrm{a}} \mathrm{d} \ln a_{\mathrm{w}}^{\mathrm{a}}+x_{\mathrm{s}}^{\mathrm{a}} \mathrm{d} \ln a_{\mathrm{s}}^{\mathrm{a}}=0
$$

The remaining unknown parameter in Equation (6) for calculating the equilibrium constant of hydration $K$ is the activity of sugar $n$-hydrate $a_{h}$ and the hydration number $n$. At infinite dilution, the activity coefficient of any chemical species would be approximated by unity. Equations (7), (9), and (10) then lead to Equations (20), (21), and (22), respectively.

$$
\begin{gathered}
a_{\mathrm{h}} \approx x_{\mathrm{h}} \\
x_{\mathrm{w}} \approx a_{\mathrm{w}}^{\mathrm{a}} \\
n_{\mathrm{a}}=n \frac{K a_{\mathrm{w}}^{n}}{1+K a_{\mathrm{w}}^{n}}
\end{gathered}
$$

Combining Equations (5), (20), and (21) yields

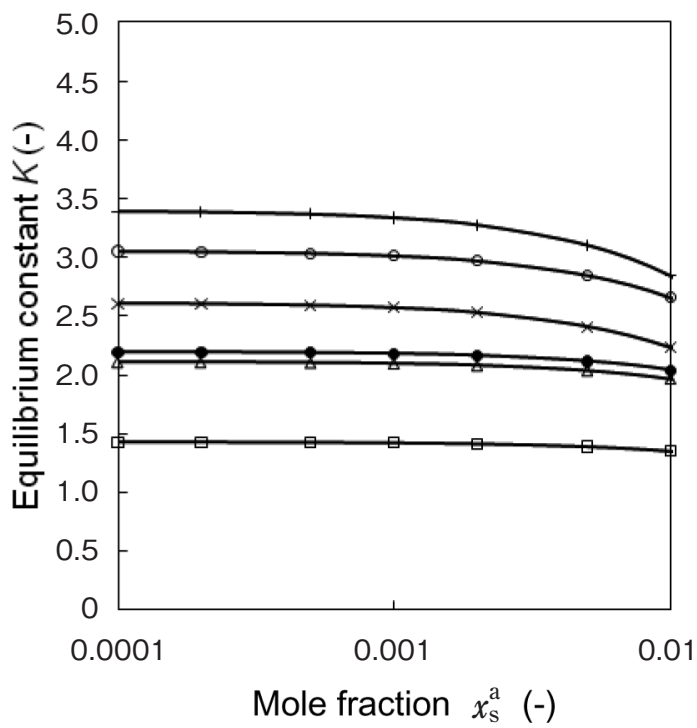

Fig. 6 Equilibrium constants of hydration of mono- and disaccharides calculated using Equation (6). $\triangle$, fructose; $\square$, glucose; $\bullet$, psicose; + , maltose; $\bigcirc$, sucrose; $\times$, trehalose. The solid curves are to guide the eye.

$$
a_{\mathrm{h}} \approx \frac{x_{\mathrm{w}}^{\mathrm{a}}-a_{\mathrm{w}}^{\mathrm{a}}}{n\left(1-x_{\mathrm{w}}^{\mathrm{a}}\right)}
$$

Consequently, the equilibrium constant $K$ and the hydration number $n$ can be obtained by solving Equations (6) and (22) simultaneously. Figure 6 shows $K$ values calculated at varied mole fractions of sugars. Values of $K$ are fairly constant at low concentrations of sugars, while they start to decrease with increasing mole fraction around 0.001 for disaccharides and for monosaccharides around 0.01 . The decreases in $K$ are considered to reflect deviations from the ideality such as non-unity values of the activity coefficient. Thus, the $K$ and $n$ values obtained for a mole fraction of 0.0001 were regarded as the equilibrium constant of hydration and the hydration number, respectively, as a first approximation. Table 1 shows that both $K$ and $n$ values of monosaccharides are smaller than those of disaccharides, suggesting that hydration of monosaccharide is less favored than that of disaccharide. Among monosaccharides, fructose and D-psicose show similar $K$ values when compared using values of the parameter $\alpha$ determined from the measurement of the vapor pressure. The larger $\alpha$ values of fructose and glucose determined from the measurement of the freezing point depression resulted in smaller $K$ values.

As mentioned already, experimentally determined values of the hydration number vary greatly depending on the experimental method. Gaïda et al. [9] have treated the hydration number $n$ and the equilibrium constant of hydration $K$ of 4 monosaccharides and 3 disaccharides as two adjustable parameters in a model for describing physicochemical properties of aqueous solutions of sugar such as the water activity. They have estimated $n$ and $K$ in order to minimize differences between experimentally obtained values of physicochemical properties and values calculated using their model [9]. The hydration number was estimated to be less than 2 for monosaccharides except for fructose, for which $n=3.4$, and more than 3 for disaccharides (Table 1). The hydration number of disaccharides increased in the order of sucrose < maltose $<$ trehalose, the same order as the average hydration number reported in this study (Table 1). Compared to the best fit approach employed by Gaïda et al. [9], the present method gave consistently larger values of $n$ and comparable values of $K$.

\section{Conclusion}

Time domain reflectometry has been confirmed to provide insights into hydration behavior of a rare sugar, 
D-psicose. The use of the dielectric relaxation time evaluated based on the assumption of a Cole-Cole type relaxation and a literature value of the hydration number of an ordinary sugar as reference has allowed the evaluation of the average hydration number of $\mathrm{D}-\mathrm{psicose}$. The quantified average hydration number was further utilized to calculate the equilibrium constant of hydration. Both the hydration number and the equilibrium constant of D-psicose were found to be almost identical with those of an epimeric stereoisomer, fructose. The results in the present study suggest that $\mathrm{D}$-psicose interacts with water in a manner similar to readily available monosaccharides such as fructose and glucose. Further investigation is required to refine the current approach: it is critical to clarify the molecular mechanism of the dielectric relaxation in aqueous solutions of sugar in order to incorporate the concentration dependence of the hydration number of sugar.

\section{Acknowledgement}

Part of this work was financially supported by the City Area Program of the Ministry of Education, Culture, Sports, Science and Technology of Japan (MEXT).

\section{Nomenclature}

$a_{\mathrm{h}}:$ activity of sugar n-hydrate, -

$a_{\mathrm{s}}:$ activity of free sugar, -

$a_{\mathrm{w}}$ : activity of free water, -

$a_{\mathrm{s}}^{\mathrm{a}}:$ apparent activity of sugar, -

$a_{\mathrm{w}}^{\mathrm{a}}:$ apparent water activity,

$c$ : speed of propagation of the light in vacuo, $\mathrm{m} \cdot \mathrm{s}^{-1}$

$d$ : geometric cell length, $\mathrm{m}$

$i$ : imaginary unit,

$K$ : equilibrium constant of hydration, -

$n$ : hydration number, -

$n_{\mathrm{a}}$ : average hydration number, -

$n_{\mathrm{h}}$ : amount of sugar $n$-hydrate, mol

$n_{\mathrm{s}}:$ amount of free sugar, mol

$n_{\mathrm{w}}:$ amount of free water, mol

$n_{\mathrm{s}}^{\mathrm{a}}:$ apparent amount of sugar, mol

$n_{\mathrm{w}}^{\mathrm{a}}:$ apparent amount of water, mol

$r_{\mathrm{s}}:$ Fourier transform of the reflected wave from a reference, -

$r_{\mathrm{x}}:$ Fourier transform of the reflected wave from a sample, -

$x_{\mathrm{h}}$ : mole fraction of sugar $n$-hydrate, -

$x_{\mathrm{s}}$ : mole fraction of free sugar, - $x_{\mathrm{w}}:$ mole fraction of free water, -

$x_{\mathrm{s}}^{\mathrm{a}}$ : apparent mole fraction of sugar, -

$x_{\mathrm{w}}^{\mathrm{a}}$ : apparent mole fraction of water, -

$\alpha$ : constant reflecting $x_{\mathrm{s}}^{\mathrm{a}}$ dependence of $a_{\mathrm{w}}^{\mathrm{a}}$, -

$\beta$ : constant reflecting the distribution of $\tau$, -

$\Delta \varepsilon$ : relaxation strength, -

$\varepsilon^{\prime}$ : real part of complex permittivity, -

$\varepsilon^{\prime \prime}$ : imaginary part of complex permittivity, -

$\varepsilon_{\mathrm{s}}^{*}$ : complex permittivity of a reference, -

$\varepsilon_{\mathrm{x}}^{*}$ : complex permittivity of a sample, -

$\varepsilon_{\infty}$ : dielectric constant at the high frequency limit, -

$\gamma_{\mathrm{d}}$ : effective cell length, $\mathrm{m}$

$\gamma_{\mathrm{h}}$ : true activity coefficient of sugar $n$-hydrate, -

$\gamma_{\mathrm{s}}$ : true activity coefficient of free sugar, -

$\gamma_{\mathrm{w}}$ : true activity coefficient of free water, -

$\gamma_{\mathrm{s}}^{\mathrm{a}}$ : apparent activity coefficient of sugar, -

$\gamma_{\mathrm{w}}^{\mathrm{a}}$ : apparent activity coefficient of water, -

$\tau$ : dielectric relaxation time, $\mathrm{s}$

$\omega$ : angular frequency, $\operatorname{rad} \cdot \mathrm{s}^{-1}$

\section{References}

1) H. Ito, T. Sato, T. Takeuchi, A. R. Khan, K. Izumori; Preparation of D-sorbose from D-tagatose by immobilized D-tagatose 3-epimerase. J. Ferment. Bioeng., 79, 184-185 (1995).

2) K. Izumori; Bioproduction strategies for rare hexose sugars. Naturwissenschaften, 89, 120-124 (2002).

3) K. Fukada, Y. Hanisawa; Hydration and viscosity of hexoses in aqueous solution. "Proceedings of the Second Symposium of International Society of Rare Sugars”, 2005, pp. 295-298.

4) K. Fukada, T. Ishii, K. Tanaka, M. Yamaji, Y. Yamaoka, K. Kobayashi, K. Izumori; Crystal structure, solubility, and mutarotation of the rare monosaccharide D-psicose. Bull. Chem. Soc. Jpn., 83, 1193-1197 (2010).

5) T. Matsuo, H. Suzuki, M. Hashiguchi, K. Izumori; D-Psicose is a rare sugar that provides no energy to growing rats. $\mathrm{J}$. Nutr. Sci. Vitaminol. (Tokyo), 48, 77-80 (2002).

6) Y. Sun, S. Hayakawa, H. Jiang, M. Ogawa, K. Izumori; Rheological characteristics of heat-induced custard pudding gels with high antioxidative activity. Biosci., Biotech. Biochem., 70, 2859-2867 (2006).

7) T. Matsuo, K. Izumori; Effects of dietary D-psicose on diurnal variation in plasma glucose and insulin concentrations of rats. Biosci. Biotech. Biochem., 70, 2081-2085 (2006).

8) K. Murao, X. Yu, W. M. Cao, H. Imachi, K. Chen, T. Muraoka, N. Kitanaka, J. Li, R. A. M. Ahmed, K. Matsumoto, T. Nishiuchi, M. Tokuda, T. Ishida; D-Psicose inhibits the expression of MCP-1 induced by high-glucose stimulation in 
HUVECs. Life Sci., 81, 592-599 (2007).

9) L. B. Gaïda, C. G. Dussap, J. B. Gros; Variable hydration of small carbohydrates for predicting equilibrium properties in diluted and concentrated solutions. Food Chem., 96, 387-401 (2006).

10) A. Gharsallaoui, B. Rogé, J. Génotelle, M. Mathlouthi; Relationships between hydration number, water activity and density of aqueous sugar solutions. Food Chem., 106, 1443-1453 (2008).

11) K. Fuchs, U. Kaatze; Molecular dynamics of carbohydrate aqueous solutions. Dielectric relaxation as a function of glucose and fructose concentration. J. Phys. Chem. B, 105 2036-2042 (2001).

12) T. Matsuoka, T. Okada, K. Murai, S. Koda; Dynamics and hydration of trehalose and maltose in concentrated solutions. J. Mol. Liq., 98-99, 317-327 (2002).

13) H. Kawai, M. Sakurai, Y. Inoue, R. Chujo, S. Kobayashi; Hydration of oligosaccharides: anomalous hydration ability of trehalose. Cryobiol., 29, 599-606 (1992).

14) H. Uedaira, H. Uedaira; Role of hydration of polyhydroxy compounds in biological systems. Cell. Mol. Biol., 47, 823-829 (2001).

15) C. Branca, S. Magazù, G. Maisano, F. Migliardo, P. Migliardo, G. Romeo; $\alpha, \alpha$-Trehalose/water solutions. 5. Hydration and viscosity in dilute and semidilute disaccharide solutions. J. Phys. Chem. B, 105, 10140-10145 (2001).

16) O. Miyawaki, A. Saito, T. Matsuo, K. Nakamura; Activity and activity coefficient of water in aqueous solutions and their relationships with solution structure parameters. Biosci. Biotech. Biochem., 61, 466-469 (1997).

17) Y. Sato, S. Kawabuchi, Y. Irimoto, O. Miyawaki; Effect of water activity and solvent-ordering on intermolecular interaction of high-methoxyl pectins in various sugar solutions. Food Hydrocolloids, 18, 527-534 (2004).

18) R. H. Cole; Evaluation of dielectric behavior by time domain spectroscopy. 1. Dielectric response by real time analysis. J. Phys. Chem., 79, 1459-1468 (1975).

19) R. H. Cole; Evaluation of dielectric behavior by time domain spectroscopy. 2. Complex permittivity. J. Phys. Chem., 79, 1469-1474 (1975).

20) R. H. Cole, S. Mashimo, P. Winsor IV; Evaluation of dielectric behavior by time domain spectroscopy. 3. Precision difference methods. J. Phys. Chem., 84, 786-793 (1980).

21) T. Ishida, M. Kawase, K. Yagi, J. Yamakawa, K. Fukada; Effects of the counterion on dielectric spectroscopy of a montmorillonite suspension over the frequency range $10^{5}-10^{10} \mathrm{~Hz}$. J. Colloid Interface Sci., 268, 121-126 (2003).

22) F. Buckley, A. A. Maryott; "Tables of dielectric dispersion data for pure liquids and dilute solutions" National Bureau of Standards Circular 589, US Government Printing Office, 1958, p. 6.

23) L. Greenspan; Humidity fixed points of binary saturated aqueous solutions. J. Res. Natl. Bur. Stand. Sect. A, Phys. Chem., 81A, 89-96 (1977).

24) P. Petong, R. Pottel, U. Kaatze; Water-ethanol mixtures at different compositions and temperatures. A dielectric relaxation study. J. Phys. Chem. A, 104, 7420-7428 (2000).

25) A. Saito, O. Miyawaki, K. Nakamura; Dielectric relaxation of aqueous solution with low-molecular-weight nonelectrolytes and its relationship with solution structure. Biosci. Biotech. Biochem., 61, 1831-1835 (1997). 


\title{
Dープシコースの誘電緩和および水分活性
}

\author{
池田新矢 ${ }^{1, \dagger}$, 合谷祥一 ${ }^{1}$, 深田和宏 ${ }^{1}$, 天羽優子 ${ }^{2}$
}

1 香川大学農学部, ${ }^{2}$ 山形大学理学部

希少糖 $\mathrm{D}$ ープシコースの水和挙動を誘電緩和および水 分活性により評価した．時間領域において計測した反 射波をフーリエ変換することにより，周波数領域にお ける誘電緩和スペクトルを求めた。得られた誘電緩和 スペクトルを Cole-Cole 式にフィッティングすること により，誘電緩和時間を算出した。グルコース，フル クトース，Dープシコース扎よびスクロース水溶液の誘 電緩和時間扎よびマルトース扎よびトレハロースの平 均水和数の文献值を用いて, グルコース, フルクトース, $\mathrm{D}$ ープシコース扎よびスクロースの平均水和数を算出し たところ， Dープシコースの平均水和数はフルクトース の平均水和数と一致した。また誘電緩和時間から求め
られた $\mathrm{D}$ ープシコースの平均水和数は，粘度の測定によ

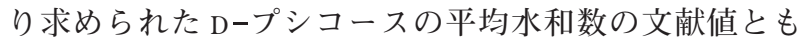
一致した.

$\mathrm{D}$ ープシコースの水分活性の濃度依存性はフルクトー スおよびグルコースの水分活性の濃度依存性とほほ一 致した。実験的に求められた水分活性と水和数，さら には糖水溶液中における物質収支を考慮して糖の水和 反応の平衡定数を求めたところ, 平衡定数の值はグル

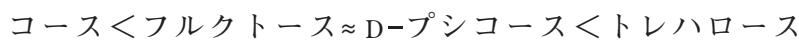
くスクロース<マルトースの順に大きくなった. D-プ シコースの水和挙動はフルクトースの水和挙動と類似 することが示された. 